\title{
Feminist tiyatro “Tiyatro Boyalı Kuş” örneği üzerinden Türkiye’deki feminist tiyatrolara genel bir bakış
}

\section{Yeşim PÍRPÍR AVAN 1}

\begin{abstract}
APA: Aydın, H. (2019). Feminist tiyatro “Tiyatro Boyalı Kuş” örneği üzerinden Türkiye’deki feminist tiyatrolara genel bir bakıș. RumeliDE Dil ve Edebiyat Araştırmaları Dergisi, (Ö6), 123-138. DOI: 10.29000/rumelide.648460.
\end{abstract}

\section{$\ddot{O} \mathbf{z}$}

Bu çalışmada, 2000 yılından bu yana feminist bir tiyatro topluluğu olarak çalışmalarını sürdüren Tiyatro Boyalı Kuş’un kurucusu Jale Karabekir ile yapılan görüşme ile feminist tiyatronun ana akım tiyatrolardan farklarına, feminist tiyatro oyunlarında metin kurgusu ve beden kullanımı arasındaki ilişkiye, feminist tiyatronun yerli-yabancı oyun seçimlerine, eril dil ile yazılmış metinlere olan yaklaşımlarına ve yabancı oyunların Türkçeye çevrilme/uyarlanma sürecine ışı tutulması amaçlanmıştır. İngiliz feminist yazar Virginia Woolf’ün 1929 yılında yayımladığı ve Jale Karabekir’in 2019'da çevirdiği/uyarladı̆̆ “ "Kendine Ait Bir Oda” adlı oyunun ardından Karabekir'e e-posta ile sekiz açık uçlu soru yöneltilmiştir. Bu sorulara verilen yanıtlar feminist çalışmalardan beslenen feminist tiyatro kuramları çerçevesinde betimsel analiz yöntemiyle incelenmiştir. Yukarıda söz edilen tiyatro oyunu ve Karabekir'in değerlendirmeleri ile sınırlı bu betimleyici çalışmada Türkiye'de özellikle 1980 sonrasında bağımsız bir şekilde yoluna devam eden kadın hareketinin feminist tiyatroların temelini attığı, bir feminist tiyatro olan Tiyatro Boyalı Kuş'un ana akım tiyatrolardan en temel farkının "kolektif yapıyı ve bilinci” uygulamak olduğu, söz konusu feminist tiyatronun eril bakış açısıyla yazılmış metinleri feminist dramaturji ile yeniden okuyarak bu metinlerde kadını nesneleştiren cinsiyetçi dili yapıbozuma uğrattığı, kadınların kendilerini ilk ağızdan anlatabilecekleri ve hem sözleriyle, hem de bedenleriyle sahnede özne konumunda yer almalarını sağlayan feminist tiyatro metinleri ürettiği ve oynadığı, yabancı oyun metinlerinin çevrilme sürecinde telif hakkı vb. hususlar ortaya çıktı̆̆ından ve sahip oldukları kısıtlı bütçeden dolayı bu feminist tiyatronun çoğunlukla oyun metinlerini kendisinin yazdığı, kısacası ülkemizdeki feminist tiyatroların ana akım tiyatrolara bir alternatif olduğu gibi sonuçlara ulaşılmıştır.

Anahtar kelimeler: Feminist tiyatro, feminist tiyatro kuramı, feminist tiyatro çevirisi, Tiyatro Boyalı Kuş.

\section{An overview of feminist theatres in Turkey in the light of a feminist theatre, "Theatre Painted Bird"}

\begin{abstract}
This study aims at presenting an overview of the differences between feminist theatres and mainstream theatres, the relation between the text and the use of the body in feminist plays, feminist theatres' choice of domestic-foreign plays, their approach to the plays written with patriarchal tradition and the translation/adaptation process of foreign plays into Turkish via the interview by Jale Karabekir, the founder of Tiyatro Boyalı Kuş (Theatre Painted Bird) which has been continuing its works as a feminist theatre community since 2000. After watching the play “A Room of One's

1 Öğr. Gör., Düzce Üniversitesi, Hakime Erciyas Yabancı Diller Yüksekokulu (Düzce, Türkiye), yesimpirpir@gmail.com, ORCID ID: oooo-0002-5315-5933 [Makale kaylt tarihi: 01.10.2019-kabul tarihi: 20.11.2019; DOI: 10.2900o/rumelide.648460]
\end{abstract}


Own" that was translated/adapted from the feminist text written by Virginia Woolf in 1929 into Turkish by Jale Karabekir in 2019, eight open-ended questions were prepared and sent to Jale Karabekir through e-mail. Her answers to the questions were analysed with the descriptive method in the light of feminist theatre theories based on feminist studies. As a result of this descriptive study, which is restricted to the above-mentioned play and its director/translator's evaluations, it is concluded that feminist movement that has continued independently especially since 1980 in Turkey is the impetus for the founding of feminist theatres, Theatre Painted Bird is fundamentally different from mainstream theatres with their collective structure and consciousness, they re-read the plays written from the male point of view with the help of feminist dramaturgy deconstructing the gendered language, so instead of the traditional plays where women are objectified and given gendered roles by men, feminist plays are produced and performed where women can explain themselves at first hand and become a subject via their words and bodies on the stage, they mostly write their own plays due to copyright costs and their limited budget, shortly, feminist theatres have become an alternative for mainstream theatres in Turkey.

Key words: Feminist theatre, feminist theatre theory, feminist theatre translation, Tiyatro Boyalı Kuş.

\section{Giriș}

“Kütüphanedeki kitapları mı kadınlardan koruyorlar, kadınları mı kitaplardan?” (Virginia Woolf, Kendine Ait Bir Oda)

Feminist tiyatronun 1960'ların sonlarında Batı'da ortaya çıkmasında deneysel tiyatro çalışmaları, yeni sol hareketi ve kadın hareketi etkili olmuştur. Feminist tiyatroya en çok ışık tutan kuşkusuz kadınların özgürlük mücadelesidir. Getirdiği yıkımdan dolayı insanlar dünya savaşları sonrasında farklı bir toplum ve yaşam hayali kurmaya başlar. Deneysel tiyatro da bu alternatif toplum inşasına katkıda bulunur. Yazar-yönetmen-oyuncu arasındaki kesin çizgiler silikleşir, metnin dokunulmazlığı tartışılmaya açılır (2006). Deneysel tiyatro, gelenekselin, alışılmışın dışına çıkarır bizi. Seyirci oyuna katılarak, oyuncuya dönüşür. Feminist tiyatro da köklerini deneysel tiyatrodan alır. Hiyerarşik düzene karşı çıkan feminist akım, tiyatroda yazar ile yönetmenin, hatta çevirmenin birlikte çalışmasıyla kendini gerçekleştirir. Kadın seyirciler, eril dille yazılan oyunlarda birer nesne olmaktan çıkar, kadın yazarların oyunlarında, hatta kadın yazarlarla birlikte doğaçlama yazdıkları oyunlarda özne konumuna yükselir.

Varlı'ya (2010) göre, toplumsal hayatta öteki konumundaki kadın, geleneksel tiyatroda da bir nesne olarak varlığını sürdürmüştür. Türkiye'de 1980'lerde gelişen bağımsız feminist hareket ise, 1990'larda feminist tiyatroların oluşumuna destek olmuştur (s. 92). Ülkemizdeki kadın hareketi 1980 askeri darbesi ile sol düşünceden yolunu ayırmıştır. Bunda, erkeklerle yan yana mücadele eden kadınların karar aşamasında gelindiğinde saf dışı bırakılmaları etkili olmuştur. Geleneksel, ana akım tiyatrolarda ataerkil bir zihniyet ile temsil edilen kadınlar, buralardan da uzaklaşıp, kendi tiyatro gruplarını oluşturmuşlardır. Kısacası, ülkemizde kadın hareketi Batı'dan daha geç yaşansa da, kadınlar hem hayat, hem de tiyatro sahnesinde artık kendilerine biçilen rolleri değil, kendi biçtikleri rolleri oynamaya başlamışlardır.

Bu çalışma ile Türkiye'deki feminist tiyatrolardan Tiyatro Boyalı Kuş'un kurucusu Jale Karabekir ile feminist tiyatro ve sahneledikleri son oyunları "Kendine Ait Bir Oda" hakkında yaptığımız görüşme, feminist tiyatro alanındaki kuramsal çalışmalar ve özellikle ülkemizdeki tiyatro araştırmacılarının görüşleri ışı̆̆ında incelenecektir. 


\subsection{Batı'da ve Türkiye'de feminist hareketin tarihçesinin ana hatları}

Batı'da feminist hareketin tarihi birçok kaynakta “dalgalar” ifadesiyle anlatılmaktadır. Birinci dalga (18. yüzyıl sonu ile 20. yüzyıl başı) kadınların erkekler gibi, onlarla eşit olmaları gerektiğini, ikinci dalga (1960’lar ve 1980’ler arası) ise kadınların erkeklerden farklı olduğunu savunurken, üçüncü dalga (1980 sonrası) kadınların da birbirlerinden farklı olduğu görüşü ile ortak ezilmişlik vurgusunun ötesinde, her kadın deneyimini biricik kılmayı amaçlamıştır (Pirpir, 2018: s.16-19). Üçüncü dalga feminizmi ekonomik, kültürel, sosyal eşitsizlikleri ve cinsel şiddeti yok etmeyi, kadınlara medya ve siyaset aracılı̆̆ıyla daha çok ulaşmayı hedef edinmiştir. ${ }^{2}$ Feminist hareketin internet ve sosyal medya kullanımın artmasıyla 2000'ler sonrasında dördüncü dalgayı yaşadığı söylenmektedir. Günümüzde kadınlar belirli sosyal platformlarda kendi deneyimlerini paylaşmakta, yapılan haksızlıklar konusunda ilgili mercilere başvurmakta veya çeşitli eylemler için bir araya gelmektedir.

Türkiye'de feminist hareketin gelişimi Batı'dakinden biraz daha geç olmuştur. Feminist hareketin tarihçesine bakıldığında, feminist tiyatronun özellikle 2000'lerde ortaya çıkmasının tesadüf olmadığını görüyoruz. Türkiye'deki kadınlar da önceleri erkeklerle eşit haklara sahip olmak için mücadele etmişlerdir. 1980 askeri darbesine kadar erkeklerle aynı safta yer alan kadınlar, darbe sonrası baskı döneminde kendilerine karar mekanizmalarında söz hakkı verilmediğini gördükten sonra siyasete olan inançlarını kaybetmişlerdir. 1990'lardan itibaren kadın hareketinde kurumsallaşmaya gidilmiş, birtakım kamu kurumları ve özel kurumlar ile dernekler kurulmuştur. 200o'lerden itibaren ise, kadınlara yönelik ırkçı ve cinsiyetçi saldırılar, etnik aidiyet ve cinsel yönelim gibi konular kadın hareketinin gündemini oluşturmaktadır. 3

Ülkemiz feminist hareket ve bu hareketten beslenen feminist tiyatro ile çeviri sayesinde tanışmıştır. Yamaner'e (2002) göre, tiyatro tarihinde başrolü her zaman erkek aldığından, tiyatro üretiminde kadının adı duyulmamıştır. Geçmişte adı duyulmayan bu kadınların yazdıkları tiyatro metinlerini günümüzde çeviri ile dilimize kazandırmamız şarttır (s. 7). Haleva'ya (2014) göre ise, "Batı toplumlarında ulusal, kültürel kimliklerin gelişmesi büyük ölçüde sanat alanındaki etkinliğin gücüyle orantılıdır ve bu noktada çeviri edimi ortak kimliğin oluşmasında rol oynar" (s. 41). Türkiye'deki kadınlar da, erkek egemenliğindeki ana akım tiyatrolara alternatif olarak kurdukları feminist tiyatro toplulukları ile kendi kimliklerini oluşturma çabasına devam etmektedir. Hem oyun yazmakta, hem de oyun çevirileri yapmaktadır. Yalnızca erkeklerin yazdığı tiyatro metinlerinin sahnelendiği veya kadın rollerinin de erkekler tarafından oynandığ dönemlerden bu yana, ataerkil zihniyete rağmen dayanışmayı ve mücadeleyi bırakmayan kadınlar sayesinde önemli bir yol katedilmiştir.

\section{Türkiye'deki feminist tiyatrolara giriş}

1990'den bu yana kadın sanatçlar tiyatro kurucusu, tiyatro sahibi, yazar, yönetmen, oyuncu ve yapımcı olarak Türkiye'deki alternatif özel tiyatroların önemli bir parçası olmaktadır (Öz ve Belkıs, 2017: s.1). Feminist tiyatrolar da alternatif tiyatrolardandır. Ülkemizde bir elin parmaklarını geçmeyecek sayıda da olsa feminist tiyatroların varlığı, kadın hareketi adına umut vericidir. Bu çalışmada tüm feminist tiyatrolara değinilmeyecektir. Çalışmamızın odak noktasını, İstanbul'da profesyonel bir feminist tiyatro topluluğu olarak kurulmuş Tiyatro Boyalı Kuş, tiyatronun kurucusu Jale Karabekir ve son oyunları Virginia Woolf ün "Kendine Ait Bir Oda" adlı eseri oluşturmaktadır.

(Çevrimiçi), https://leadercochise.wordpress.com/2017/02/22/3-dalga-feminizm/ , 23.05.2019.

Daha detaylı bilgi için bkz. Pirpir, 2018: s.25-42. 


\title{
2.1. Tiyatro Boyalı Kuş'un kurucusu Jale Karabekir hakkında
}

Yazar, oyuncu ve çevirmen Jale Karabekir İstanbul Üniversitesi Dramaturji ve Tiyatro Eleştirmenliği Bölümü’nde lisans, Boğaziçi Üniversitesi Sosyoloji Bölümü'nde ise yüksek lisans eğitimi almıştır. Işık Üniversitesi İnsan ve Toplum Bilimleri Bölümü’nde yarı zamanlı öğretim görevlisi olarak ders vermektedir. 2000 yılında kurduğu Tiyatro Boyalı Kuş'ta hem performansa dayanan feminist tiyatro çalışmaları, hem de feminist dramaturjiyle okuma tiyatrosu etkinlikleri düzenlemektedir. Bu çalışmaları özellikle gönüllülerle ve kadınlarla yürütmektedir. Yazarın toplumsal cinsiyet ve performans alanında akademik çalı̧̧maları mevcuttur.4 "Türkiye'de Kadınlarla Ezilenlerin Tiyatrosu, Feminist Bir Metodolojiye Doğru" 5 adlı kitabının arka kapağında Augusto Boal'ün "Yeni teori ancak sürekli pratikten doğacaktır." sözüne de yer veren yazarın yaptığı çalışmalara bakıldığında teori ile pratiği birleştirme çabası açıkça görülmektedir.

\subsection{Kendine Ait Bir Oda'nın Türk edebiyatındaki ve tiyatrodaki dolaşımı}

1929'da yayımladığı "Kendine Ait Bir Oda" (A Room of One's Own) adlı eserde Virginia Woolf tarih boyunca erkek egemen anlayışın kadınlara karşı takındığı cinsiyetçi tutumu gerçek ve kurmaca karakterler ile anlatmaya çalışır. Bu eser feminist düşüncenin temel taşlarından kabul edilmektedir. Nadir Kitap adlı bir sahaf sitesinde Kendine Ait Bir Oda'nın Türkçeye 1987 yllında Suğra Öncü tarafından kazandırıldığı görülmektedir. ${ }^{6}$ Sonraki yıllarda da bu eserin farklı çevirmenler tarafından Türkçeye çevrildiğini görüyoruz.

Kendine Ait Bir Oda ilk defa 1989'da İngiliz yazar ve tiyatro yönetmeni Patrick Garland tarafindan sahneye uyarlanmış ve 1990-91 yıllarında oynanmıştır.7 Bu eserin Türk tiyatrolarındaki dolaşımını ise eseri sahnelemek üzere derleyen ve çeviren ve aynı zamanda oyunun yönetmenliğini yapan Semih Fırıncıoğlu başlatmıştır. Bu metin ilk kez 12 Mayıs 1993’te İstanbul Aksanat’ta sahnelenmiştir. Orijinali yaklaşık 100 sayfa olan eserin Fırıncıoğlu tarafından oluşturulan tiyatro metni 17 sayfa uzunluğundadır. ${ }^{8}$ Metin boyutunda bir inceleme bu çalışma kapsamına girmemektedir, ancak Firıncığlu'nun bu eserle ilgili bir internet sitesindeki sözlerine yer vermek metni çeviri-uyarlama süreci hakkında fikir sahibi olmamızı sağlayacaktır.

\begin{abstract}
“Garland'ın derlediği metnin Türkiye izleyicisine anlaşılmaz gelecek, fazlaca "İngiliz” seçimlerden oluştuğu ve monoloğun bana ilginç gelen bir teatralliğinin olmadığı sonucuna vardım. Selışık ve Saban'a yeni bir derleme ve çeviri yapıp yönetebileceğimi bildirdim, kabul ettiler. Ekteki metin bu derlemenin metnidir: Woolf un Kendine Ait Bir Oda'sını kaynak olarak kullanması ve tek kişilik bir oyun olması dışında Garland’ın metniyle pek bir ilişkisi yok.”9
\end{abstract}

Bu sözlerden anlaşılacă̆ı üzere, Fırıncıŏglu Woolfün kaleme aldığı metni değil, İngiliz yazar ve tiyatro yönetmeninin oyununu kullanmıştır. Bu nedenle kaynak metnin bire bir çevirisini yapmamış, İngilizce tiyatro oyunundan bir nevi esinlenmiştir.

Kendine Ait Bir Oda, günümüzde, yani yazıldığı tarihten tam doksan yll sonra alternatif tiyatro topluluklarında yeniden hayat bulmaktadır. Tiyatro, müzik ve film alanında çağdaş olanın araştırılması

(Çevrimiçi), https://tiyatrolar.com.tr/jale-karabekir , 22.05.2019.

Karabekir, J. (2015). Türkiye'de Kadmlarla Ezilenlerin Tiyatrosu, Feminist Bir Metodolojiye Doğru, İstanbul: Agora Kitaplı̆̆ı.

Woolf, V. (1987). Kendine Ait Bir Oda. (S. Öncü, Çev.). İstanbul: AFA.

Performans için bkz. https://digital.films.com/p_ViewPlaylist.aspx?AssignmentId=ABPNDQ, 22.05.2019.

(Çevrimiçi), https://isteyenokusun.files.wordpress.com/2014/11/kendine-ait-bir-oda_v-woolf.pdf, 22.05.2019.

(Çevrimiçi), https://isteyenokusun.com/tag/virginia-woolf-kendine-ait-bir-oda/ , 22.05.2019. 
ve uygulanması ilkesiyle hareket eden ve çeşitli disiplinlerden birçok sanatçı ve tasarımcıyla ortak projeler üreten ${ }^{10}$ Tayf Kolektifin sonuncusunu 16 Mayıs 2019'da SahneBeşiktaş’ta sergilediği "Kendine Ait Dört Oda” adlı oyunu aslında bu eserden değil, Virginia Woolfün kendisinden yola çıkılarak kurgulanmıştır. Oyunun yazarı ve yönetmeni Umut Kırcalı oyunu şu sözlerle anlatmaktadır:

"Virginia Woolfü merkeze alan oyun, Woolf'un trajik ölümüne ve intiharı öncesindeki son anlarına odaklanıyor. Eşi Leonard Woolfa yazdı̆̆ı veda mektubundan yola çıkılarak yazılan metni, elli dakikalık çağdaş müzik bestesi olarak tasarlanan oyun kaydı ve soyut sahneleme biçimiyle, performans, müzik ve şiir dinletisini bir araya getiren proje, savaşın ve yıkımların hüküm sürdüğü bir dünyada eserleriyle yepyeni bir dünya yaratan Virginia Woolfun, yazı masasındaki tek başınalığını, yaşadığı buhranı ve onu intihara sürükleyen karanlı̆̆ı şiirsel bir dille sahneye taşıyor.”11

Endüstri mühendisliği mezunu Kırcalı'nın tiyatro eğitimi Stüdyo Oyuncuları ile başlamıştır. Kırcalı'nın verdiği röportajda (bkz. 9 numaralı dipnot) oyunda yazılı bir metnin olmadığını, oyunun dilinin daha çok seslerden ve işılklardan oluştuğunu öğreniyoruz.

\title{
2.3. Tiyatro Boyalı Kuş yorumuyla "Kendine Ait Bir Oda"
}

\author{
"İstediğiniz kadar kütüphanelerinizi kilitleyiniz, \\ ne kadar kapınız, ne kadar kilidiniz, ne kadar sürgünüz olursa olsun, \\ zihnimin özgürlüğüne ket vuramazsınız!” (Virginia Woolf) ${ }^{12}$
}

Türkçeye çevirisi, sahne metnine dönüştürülmesi ve yönetmenliği Jale Karabekir tarafından yapılan "Kendine Ait Bir Oda" adlı oyun doksan dakikalık tek perde şeklinde Cihangir Performans'ta (bu mekânda sonuncusu 12 Mayıs 2019'da olmak üzere dokuz kere ve bir kere 15 Haziran 2019'da Kadın Eserleri Kütüphanesi'nde) sahnelenmiştir. Bu oyun siyah kıyafetli beş kadın oyuncu tarafından bir apartman dairesinin iki farklı odasında oynanmıştır. Oyun sırasında oyuncular bu odaların iç ve dış özelliklerini kullanmışlardır. Oyuna "mekâna özgü performans" denilme sebebi budur. Oyun öncesinde Karabekir'e oyunun kayda alınıp alınamayacağı sorulmuştur. Mekânın aktif olarak kullanılmasının bunu zorlaştıracağını belirten Karabekir, oyun sonrasında oyunla ilgili her türlü soru ve düşüncelere açık olduğunu dile getirmiştir. Daha önce de belirtildiği gibi, metin düzeyinde bir inceleme bu çalışma kapsamına girmediğinden, bu oyunla ilgili genel bilgilere Karabekir ile yapılan görüşme ve bu görüşmenin analizi üzerinden ulaşılması amaçlanmaktadır.

\section{Kuramsal çerçeve}

Bu bölümde Batı'da ve Türkiye'de feminist tiyatro çalışmalarına ışı tutan ve aynı zamanda feminist tiyatro çalışmalarından beslenen kuramsal yaklaşımlara kısaca değinilecektir. Tiyatro alanındaki kuramlar doğrudan performans ve deneyimden doğar. "Feminist tiyatro kuramı" şemsiye terimi altında üretilen kuramsal çalışmalar da, kadınların hem özel hayatlarındaki, hem de toplumsal hayattaki "kadınlık deneyimleri"nden yola çıkılarak oluşturulmaktadır. "Feminist tiyatroların farklı coğrafyalardaki toplumsal, kültürel ve sınıfsal dinamikleri ve toplumsal cinsiyet kavramının farklı görünümlerine karşın bazı ortak stratejileri paylaştığı ... görülür” (Savaşkan, 2018: s. 35). Feminist tiyatro tüm dünyada feminist akımla birlikte gelişmekte, kadınların ataerkil düzende "ses"lerini

(Çevrimiçi), https://tiyatrolar.com.tr/tayfkolektif/?s=hakkinda , 22.05.2019.

(Çevrimiçi), https://www.nouvart.net/kendine-ait-dort-oda-virginia-woolf-dort-oda-umut-kircali-roportaji/ 22.05.2019.

Tiyatro Boyalı Kuş'un resmi internet sitesinde oyunun tanıtıldı̆̆ sayfada Virginia Woolften yapılan alıntı. https://tiyatroboyalikus.blogspot.com/, 30.09.2019. 
duyuramadıkları yerlerde meselelerini "beden"leriyle anlatmalarına izin vermektedir. Bu meseleler toplumdan topluma değişiklik gösterse de, özünde aynı yere çıkar: ataerkil tahakküme karşı çlkmak.

\title{
3.1. Feminist tiyatro kuramına doğru
}

\begin{abstract}
"Hiç belli olmaz, bakarsınız günün birinde, farklılığın kutuplaşmış ikiliklerin sınırlarına hapsolmadığı düşünsel ve siyasal bir iklimde, bugün ancak bir özlem olarak var olabilen 'cinsiyet tanımayan akıl ve insan' kavramı, gerçeğe dönüşür. Ama o zamana dek, cinsiyetlendirilmiş bir tarihin, teorinin ve felsefenin peşine düştüğümüz için bizi kim kınayabilir?” (Fatmagül Berktay, Tarihin Cinsiyeti)
\end{abstract}

Feminist tiyatro şüphesiz ki feminist hareketten etkilenmiştir. Hooks'a (2016) göre, "feminizm cinsiyetçiliği, cinsiyetçi sömürüyü ve baskıyı sona erdirmeye çalışan bir harekettir” (s. 9). Bu sözlerde feminist hareketin çıkış noktasını görebiliyoruz. Kadınlar erkeklerin yazdığı tarihin (tozlu ve eksik) sayfalarından çıkıp bu sayfaları yeniden yazmaya başlamıştır.

\subsection{Feminist tiyatro kuramı oluşturmaya yönelik çalışmalar}

Feminist tiyatronun feminist hareketten ve feminist kuramdan etkilendiği açıktır. Feminist tiyatro feminist kuram dışında pek çok ötekilik-karşıtı ideolojiden beslenen bir yaklaşım olarak da tanımlanabilir. Feminist tiyatro çalışmaları 1990'lara kadar tiyatro tarihini sorgularken, 2000 sonrasında oyun metinlerinin incelenmesi ve analiz yöntemlerinin sorgulanmasını hedef almaktadır. Hem performans çözümlemeleri, hem de feminist çerçevede yazar ve metin incelemeleri ve eleştirileri yapılmaktadır (Belkıs, 2015: s. 63). Feminist tiyatro kuramı feminist eleştiriden beslenmektedir. Yamaner'e göre,

\begin{abstract}
"Feminist eleştirel teori, ilgili disiplinler bağlamında feminist projelerden "ödünç” bakış açıları almaya başlamıştır. Örneğin 'klâsiklerdeki', yerleşmiş olan erkek-yazarların imajına göre belirlenen kadın imgesini yıkma, dönüştürme çabaları tiyatroda da feminist mücadelenin diğer alanlardaki hareket alanıyla paralel bir çizgidedir. Bu anlamda tiyatroya feminist bakış, içinden çıktığı feminist teori ve hareketin yolundan ilerlemektedir." (Yamaner, 2001: s. 14).
\end{abstract}

Diğer bir deyişle, ataerkil dille kaleme alınmış eserler masaya yatırılarak feminist eleştiri ile yapıbozuma uğratılırken, feminist tiyatro kuramı tiyatro metinlerinde kullanılan dili inceleyerek, bu zihniyetle yazılmış metinlerin sahnede (ve aslında gerçek hayatta) kadınlara nasıl "söz hakkı vermediğini” tespit eder. Kadın yazarlar kadınların kendilerini hem kelimelerle hem de bedenleriyle rahat bir şekilde ifade edebilecekleri oyunlar yazmak için kolları sıvarlar. Ataerkil zihniyeti yansıtan eski oyunları da feminist bir bakış açısıyla yeniden okurlar. Kısacası, feminist tiyatro kuramı da, feminist kuram gibi, kadınlık meseleleriyle ilgilenir, sahnede kadın sorunlarını betimlerken, kadınların feminist bilincini yükselterek çıkmazda olan kadınlara bir çıkış yolu gösterir.

Feminist tiyatro kuramına yönelik çalışmalar, sadece kadınları özgürleştirmenin yolunu yapmakla kalmaz, aynı zamanda ana akım denilen, geleneksel-sosyal yapıdan kopamamış tiyatrolara da yeni bir nefes getirir. Tiyatronun doğasına, tiyatromuzun bileşenlerine yönelik de bir sorgulama alanı açar (ibid, s. 65). Kadının toplumda ezilmişliğinin sahnede yeniden üretilmesinin önüne geçmeye çalışır. 


\section{Değerlendirme}

\subsection{Jale Karabekir ile feminist tiyatroya ve "Kendine Ait Bir Oda”ya dair bir görüşme}

Tiyatro Boyalı Kuş'un kurucusu Jale Karabekir ile Kendine Ait Bir Oda adlı oyunu sonrasında e-posta yolu ile bir görüşme gerçekleştirilmiştir. Feminist tiyatronun hem kuramsal hem de performans boyutuyla ilgilenen Karabekir'e sekiz açık uçlu soru yöneltilmiştir. Bu sorulara verilen yanıtlar betimsel analiz yöntemiyle incelenmiştir ve bu analizin özellikle Türkiye'deki feminist tiyatrolara dair birçok noktayı aydınlattı̆̆ı düşünülmektedir. Görüşme soruları şunlardır:

Tiyatro Boyalı Kuş ile Sayın Güzin Yamaner hocanın danışmanlığında yazılmış, "Üçüncü Tiyatro ve Türkiye'de Kadın Tiyatroları" adlı yüksek lisans tezi sayesinde (iyi ki) tanıştım. Ülkemizde özellikle 1990 sonrasında oluşum gösteren feminist tiyatro toplulukları arasında Tiyatro Boyalı Kuş da. Peki, feminist tiyatronun geleneksel tiyatrodan farkı nedir?

Karşımızda eril öğelerle dolu bir dil ve toplum gerçeği var. Feminist tiyatro bu alıșılagelmiș düzene/geleneklere nasıl "dur" diyor? Feminist tiyatro kuramının yapı bozuma uğrattığı (ve yeni anlamlar yüklediği) kavramlar var mı? Bunlara örnekler verebilir misiniz?

Kadınlar yüzyıllardır hem sahnede, hem de gerçek hayatta kendilerine erkekler tarafından biçilen rolleri oynamakta. Feminist tiyatro sahnesinde metin kurgusu ve beden kullanımı arasında nasıl bir ilişki seyreder? (oyuncu-beden-sahne-dil ilişkisi bağlamında kısaca bahsedebilir misiniz?)

Tiyatro Boyalı Kuş'un internet sitesinde bir tarama yaptığımda bugüne kadar oynanan oyunların tamamına yakınının Türkçe olduğunu gördüm. Bunun özel bir sebebi var mıdır? (kültürel, sosyal, politik vb.) Gelecekte yabancı oyunlara da yer vermeyi düşünüyor musunuz?

Okumalarım sonucu feminist tiyatro topluluklarının güncel konuları işlemek adına oyun metinlerini çoğunlukla kendilerinin yazdığı ya da eril bir dille kaleme alınmış metinleri uyarladığı sonucuna vardım. Bu metinler sadece kadınlara mı seslenmekte? Feminist tiyatronun kadın sorunlarının çözümüne katkısı nedir?

Virginia Woolfün “Kendine Ait Bir Oda” adlı eserini 12 Mayıs Pazar günü Cihangir Performans'ta Tiyatro Boyalı Kuş yorumu ile izledim. Sizinle de oyun sonrası kısa bir sohbet şansını yakaladım. Bu eserin çevirisi ve sahne metnine dönüştürülmesi sizin elinizden çıtı. Bu süreçten biraz bahsedebilir misiniz? (bu eseri neden seçtiğiniz, çeviri yaparken dikkat ettiğiniz dilsel-kültürel noktalar, kaynak metne ne kadar bağlı kaldığınız vb.)

Oyunun beş kadın oyuncu tarafından oynanmasının bir anlamı var mıdır? Oyuncular neden siyah kıyafetler içindelerdi?

Bu oyunda beni çok etkileyen sözlerden biri; "Kütüphanedeki kitapları mı kadınlardan koruyorlar, kadınları mı kitaplardan?” Bugün ülkemizde feminist hareketin geldiği noktayı ve bu hareketin kadınlara yansımasını nasıl görüyorsunuz? (Görüşmenin tam metni ektedir).

\subsection{Araştırmanın yöntemi}

Araştırmada başvurulan betimsel analizin amacı, toplanan verileri düzenlenmiş ve yorumlanmış olarak sunmaktır. İlk önce veriler betimlenir, sonra bu betimlemeler açıklanır ve yorumlanır, aralarındaki neden-sonuç ilişkileri incelenir ve bazı sonuçlar elde edilir (Şimşek ve Yıldırım, 2016: s. 239). Bu çalışmada görüşme yoluyla toplanan veriler araştırma soruları doğrultusunda belirlenen temalara veya görüşme ve gözlem süreçlerinde sorulan sorulara göre düzenlenmiştir. Görüşülen kişinin sözlerinden yer yer alıntı yapılarak bu kişinin görüşlerinin etkileyici bir şekilde okura iletilmesi sağlanmıştır.

\subsection{Görüşmenin değerlendirilmesi}

Görüşmenin 1. sorusu "feminist tiyatronun diğer tiyatrolardan farkını" ortaya çıkarmaya yöneliktir. Karabekir öncelikle soruda kullanılan "geleneksel" tiyatro kavramını düzeltme yoluna gitmiştir. Geleneksel tiyatro denilince akla ilk olarak gölge oyunları (Hacıvat-Karagöz), orta oyunu gibi Türk 
kültürüne özgü tiyatro oyunlarının geldiğini dile getiren yazar, günümüzde feminist tiyatronun ana akım tiyatronun karşısında durduğunun altını çizer. Feminist tiyatronun feminist bir ideolojisi vardır. Tiyatro Boyalı Kuş'un Batı tarafından üretilen feminist tiyatro kategorilerinden (Liberal, Marksist, Radikal gibi) herhangi birine girmediğini, ancak hepsinden farklı özellikleri bünyesinde barındırdığını söyler. "Çalışma yöntemlerimizden, ekip içindeki hiyerarşik düzene kadar, metin seçimi, metne bakış, sahneleme, oyunculuk, kostüm, sşık, müzik, ses her şeyi titizlikle düşünüyoruz, seyirciye seslendiğimiz her alanın (seyirciyi karşılama performansı da dâhil) bizim iletimizde yeri var. Sonuçta kadın tiyatrosu değiliz, karma bir yapımız var. Karar mekanizmasında ise sadece kadınlar yer alıyor. Buna önem veriyoruz." sözlerinden feminist tiyatronun hangi açılardan farklı olduğu anlaşılmaktadır. Karabekir ayrıca ana akım tiyatronun demokratik bir yapısının olmadığını, kendilerinin ise olabildiğince hiyerarşik yapıdan kaçınmaya çalıştıklarını belirtir. Savaşkan'a (2018) göre, feminist tiyatrolarda kolektif üretim çok önemlidir. Bu, yazarla ve feminist gruplarla birlikte çalışmayı gerektirir. Performans, yapılacağı mekâna, bölgeye, seyirci kitlesine vb. hususlara göre sahnelenmektedir (s. 35). Karabekir eril bakış açısıyla yazılmış eski tiyatro metinlerini feminist bir dramaturji ile uyarladıklarını ileri sürer. "Kadın imgesinin ve bedeninin nesne olarak temsili, cinsel obje olarak tekrar sahnede üretilmesi; cinsiyetçi sözler, cümleler, kalıplar; argonun sahneye taşınması gibi unsurlara da karşı durduğumuzu söyleyebiliriz." diyen yazar feminist tiyatronun ana akım tiyatrolardan açık bir şekilde ayrıldığını gözler önüne sermiştir. Feminist tiyatro; metin, yazar, sahneleme, dil, amaç ve benzeri tiyatral noktalarda benzerliklerle üretilmiştir. Sahne feminizm tarafından ataerkil düzenin araçlarını ortaya çıkarmak ve kadınları ortak meseleleri için çözüm yolları bulmak üzere buluşturan bir yer halini almıştır (Gül, 2009).

Görüşmenin 2.sorusu "feminist tiyatro kuramının eril dili nasıl yapıma bozuma uğrattığını" ve "toplumdaki ataerkil düzene nasıl karşı geldiğini” öğrenmek üzere sorulmuştur. Karabekir, çıkış noktalarının feminist dramaturji olduğunu dile getirir. Feminizmin erkek düşmanlığı olarak algılandığı dönemde feminist tiyatro yapmaya başladıklarını ve insanların algısının değişeceği yönündeki umutlarını yitirmediklerini belirtir.

"Dilin, kavramların değişmesi her şeyden daha önemli ama bir yandan da güç. Bu anlamda sahneleyeceğimiz metinlerin feminist dramaturjiyle ele alınması en önemli adımımız diyebiliriz.”

Metin çözümlemelerinde feminist dramaturjinin yapıbozum tekniğinden yararlandığını dile getiren Karabekir, TEB Oyun Dergisi’ndeki röportajında da Tiyatro Boyalı Kuş’un feminist dramaturji ile yaptığı okuma tiyatrosu etkinliklerinden bahseder.
"Bu coğrafyada yazılmış metinlerle hesaplaşmaya çalışıyoruz. Örneğin, Namık Kemal’in Vatan Yahut Silistre metnini13, feminist okumasını yaparak seyirciyle buluştururken, milliyetçilik, toplumsal cinsiyet, militarizm gibi meselelere bugünün eleştirel anlayışıyla yaklaştık. Genel olarak okuma tiyatrolarımızda metin üzerinde yapıbozum yöntemlerini kullanıyoruz. Eski metinleri yapıbozuma uğratarak ... metnin seyirciyle eleştirel biçimde karşılaşmasıını amaçlıyoruz.” (Savaşkan, 2018: 49).

Feminist dramaturjide erkeklerin eril bir dille yazdığı metinler ele alınır. Bu metinlerdeki kadın düşmanı noktalar ve kadın imgeleri ortaya çıkarılır. Kadınların tiyatro tarihindeki konumlanışı bu verilerden yola çıkılarak yeniden yazılır. Ayrıca Shakespeare gibi önemli klasik oyun yazarlarının eserleri gözden geçirilir ve mitolojideki kadın hikâyeleri yeniden anlatılır. Bu hikâyelerdeki kadın karakterler aynıdır, ancak hikâyelerin akışı feminist bir bakış açısıyla değiştirilerek eserler sahnede yeniden üretilir (2006: 8).

\footnotetext{
13 Tiyatro Boyalı Kuş’un feminist dramaturji ile ele aldığı Türk tiyatro oyunları hakkında daha fazla bilgi almak için bkz. http://tiyatroboyalikus.blogspot.com/2015/o9/feminist-dramaturjiyle-okuma-tiyatrosu.html 
Tiyatro Boyalı Kuş ile on dokuz yıldır feminist söylemi ve pratiği feminist tiyatroda buluşturduklarının altını çizen Karabekir, ana akım, eril tiyatroların dikkatlerini çektiklerini, artık hem tiyatrocuların hem de seyircinin, kadının sahnede eril temsilini fark ettiklerini ve feminist tiyatro oyunlariyla karşılaştırabildiklerini ileri sürer. Bu, ataerkil düzenin değişmesi yolunda önemli bir farkındalıktır.

3. soru "feminist tiyatro sahnesinde metin kurgusu ve beden kullanımı arasındaki ilişkiye" dair bilgi toplamak amacıyla yöneltilmiştir. Yazardan "oyuncu-beden-sahne-dil ilişkisi”nden kısaca bahsetmesi istenmiştir. Feminist tiyatro metinlerinin okunmaktan ziyade sahnelenmek adına oluşturulduğunu vurgulayan Karabekir, feminist bir oyunun sahnede izlenmeden anlaşılmasının pek mümkün olmadığını söyler. Feminist tiyatronun "beden ve dil”i ana akım, eril tiyatrolardan farklı şekillerde kullandıklarını şu sözleriyle ifade eder:

"Dili yabancılaştırmıyoruz, ama dilin içindeki bazı kuralları değiştiriyoruz. Bunu seyircinin anlamı için fazla dikkatli olması gerekiyor tabii. Dilin eril yapısını değiştirmek, cinsiyetçi yapıları kullanmamak, kadını nesne değil, özne yapmak, sözü ve aksiyonu kadından yana kullanmak önem verdiğimiz noktalar."

Tiyatronun doğduğu dönemlere gidilirse, eski Yunan ve Roma tiyatrosunda ilk kadın oyun yazarlarının sanatlarını beden diliyle gerçekleştirdikleri görülür. Bunlar sokaklarda gösteriler yapan kadın mimcilerdir. Metinlerini bedenleriyle üretmişlerdir. Çünkü ataerkil yönetim anlayışına bağlı tiyatro sistemlerinde yazmak erkeklere verilen bir ayrıcalıktı. Bu kadınların performansları dönemin diğer oyunları kadar önemli olsa da, yazılı tarihe geçmedikleri için bugün onlara ulaşamıyoruz. Bu kadın mimciler feminist bir bağlam içerisinde, oyun yazarları olarak tanımlanabilirler (Case, 2010: s. 63-64). Günümüzde kadınlar oyunlar yazmakta veya farklı rollerle sahneye çıkabilmektedir. Ancak ana akım tiyatrolarda, erkekler tarafından yazılan oyunların çoğunda kadının özne konumunda olmadığı, cinsiyetçi ayrımların bu oyunlarla tekrar ve tekrar üretilip topluma yansıtıldığı bir gerçektir. Feminist tiyatrolar kadınlara kendilerini "erkek gözüyle” değil de, kendi bakış açılarıyla görüp oynama şansını vermiştir. Kadınlar sahnede bedenlerini istedikleri gibi kullanmış ve istediklerini söylemişlerdir.

4. soru Tiyatro Boyalı Kuş’un “yerli ve yabancı oyun repertuarını” öğrenmeye yöneliktir. Bu soru özellikle feminist tiyatronun çeviri oyunlara ne kadar yer verdiğini ortaya çıkarmak için sorulmuştur. Karabekir, August Strindberg, Henrik Ibsen, Caryl Churchill, Svetlana Aleksiyeviç gibi yabancı yazarların oyunlarını sahnelediklerini; Shakespeare, Aristofanes ve Evripidis gibi yazarların metinlerinden yola çıkarak yeni metinler ürettiklerini söyler. Yani hem çeviri, hem de uyarlama yoluna gitmişlerdir. Ibsen’in Nora-Bir Bebek Evi oyununu ise Türkçe değil, Kürtçe olarak sahnelemişlerdir. Ancak 2018'den bu yana bu oyun İstanbul Şehir Tiyatrosu'nda Jale Karabekir-Feride Eralp çevirisi ile sahnelenmektedir. Feminist oyun metni bulmakta güçlük çektiklerini, dramaturji kökenli oldukları için ekip arkadaşlarının yazdığı oyunları sahnelediklerini belirtir. Özellikle fazla Batılı söylemler içerdiklerinden her yabancı feminist metnin de toplumumuza uygun olmadığını dile getiren yazar, çeviri oyunlara pek yer vermediklerini belirtir. Bir başka önemli sebep ise ekonomiktir.

“2014 yılından beri sabit bir bütçeye/fona sahip olmamamızdan ileri gelen, ülkenin ekonomik ve politik baskıları dolayısıyla da telif (yazar ve çevirmen) oyunları oynamanın mali yükünü kaldıramayacă̆ımızın bilincindeyiz."

5. soru ise "feminist tiyatro metinlerinin hedef seyirci kitlesi"ni ve "kadın sorunlarının çözümüne katkısı"nı ortaya çıkarmaya yöneliktir. Tiyatro Boyalı Kuş’ta oynanan oyunlar genel anlamda kadınlara 
seslense de, birçoğu hem kadın hem de erkek seyirciye açık.14 Son oyunları "Kendine Ait Bir Oda"nın kadınlara seslendiğini belirten Karabekir, erkek seyirci için de farklı bir deneyim olduğunun altını çizer. Ancak önceki oyunlarının özellikle kadınlara seslendiğini düşünmemektedir. "Dönüşümün tüm toplumda olması gerektiğinin farkındayız. Topluluğumuzun karma olmasının nedenlerinden biri de bu.” Yazar tiyatronun özellikle sosyal medyanın ve internetin öne çıtı̆̆ı dönemde kadın sorunlarını çözmede yetersiz kalacağını imâ eder. Tiyatronun sanalı değil, gerçeği yansıttığını söyler. Özellikle atölye çalışmalarında kullandıkları Ezilenlerin Tiyatrosu Tekniğinden ise şu sözlerle bahseder:

\begin{abstract}
“Tiyatro gerçek ilişkiyi temsil ediyor benim için, insani olan. Etkileşimin gerçek olduğu, o nedenle samimi olması şart. Ezilenlerin Tiyatrosu bu anlamda daha katılımcı ve daha etkileşimli bir yöntem. Kadın meselelerine yaklaşım ve bilinç yükseltme açısından daha etkili buluyorum. Zaten bizim de çalıştı̆̆ımız bir dal bu."
\end{abstract}

6. soru Virginia Woolfün "Kendine Ait Bir Oda" adlı eserinin "seçim ve çeviri sürecini” aydınlatma amacıyla yöneltilmiştir. Karabekir, tiyatro ekibine katılanlara yıllardır "Kendine Ait Bir Oda" ve "Feminist Teori" kitaplarını önerdiklerini dile getirir. Bu yıl bir dramaturg arkadaşlarının bu eserden etkilenip çalışmaya geldiğini ve kendisinin de bu eseri "sahnelenebilir mi" sorusuyla yeniden okuduğunu ifade eder. Bu süreci şu sözlerle anlatır:

"Kendine Ait Bir Oda”nın içerdiği aksiyon, hareket ve temalar üzerine doğaçlamalar yapıyorduk. Derken bölüm bölüm metnin dramaturjisini yapmaya ve Türkçeleştirmeye ve sahneye uyarlamaya başladım. Metin hiyerarşisi olmadan bu yeni ekiple çalıştığımız için, aslında hem yeni bir ekip ruhu oluştu, hem de oyuncunun bedensel hareket ve yaratım özgürlüğünü yakalama firsatı bulduk. Daha sonra oyuncularla da metindeki temalar ve bizim ekip olarak o temalara yakınlığımız, uzaklığımız, kendi engellerimiz vs. üzerine tartıştık ve çalıştık.”

Kendine Ait Bir Oda ilk kez 7 Nisan 2019'da sahnelenir. Metin zor olsa da, hala güncelliğini koruduğunu belirten yazara göre, bu oyunun kendilerine en büyük katkısı Woolfün de bahsettiği odanın fiziksel bir oda değil, Tiyatro Boyalı Kuş'un kendisinin olduğunu fark etmeleridir. Karabekir ile oyun sonrası yaptığımız sohbette, bu eseri çevirirken nasıl bir strateji izlediğini, nelere dikkat ettiğini sormuştum. Eserin de yazıldığı dönemi dikkate alarak metnin çevirisinde eski Türkçe kelimeler seçtiğini, ancak metni değiştirme yoluna gitmediğini belirtmiştir. Buradan yazarın kaynak metne bağlı kaldığı çıkarımında bulunabilir.

7. soru Kendine Ait Bir Oda adlı oyunun "fiziki yapısına" yöneliktir. Bu oyun birbirinin yerine geçen beş kadın oyuncuyla oynanmıştır. Bu kadınlar sade, siyah elbiseler giymektedir. Karabekir oyuncu sayısına bilinçli bir şekilde karar vermeseler de, 3, 5,7 ve 9 rakamlarının tarihte kadim rakamlar olduğunu ileri sürer. Ancak oyuncu sayısını provaların ve gösterimlerin sağlıklı yürütülebilmesi için az tutmaya çalıştıklarını belirtir. Yazar sahnedeki beş kadın oyuncunun birbirinin yerine geçmesinin ve kıyafetlerinin siyah renkte olmasının sebeplerini şöyle anlatıyor:

"Siyah sahnede nötr bir renk. Virginia Woolf, kadın üniversitesinde kadın öğrencilere bir konuşma yapıyor. Woolf'un bilinçakışı yöntemini kullandığını biliyoruz, bu metinde de kullanıyor, bunu sahnelemede nasıl gösterebiliriz diye düşününce, bu bilinçakışını farklı düşüncelerin oyun yerinde bedenleşmesi ve Woolf'la ve seyirciyle konuşması olarak bulduk. Diğer dört oyuncu Woolfun zihnindeki düşünceleri temsil ediyor. Çoğunlukla cinsiyetsizler. Şekilden şekile girebiliyorlar, kişiden kişiye dönüşebiliyorlar, çünkü kişi değil düşünceler. O nedenle bu fikrimizi seyirciye verebilmek için de nötr bir renk ve kostümde karar kıldık.” yöneliktir. (Çevrimiçi), http://tiyatroboyalikus.blogspot.com/2015/o9/guz-2016-atolye-calismalari_28.html, 24.05.2019. 
Yazar ülkemizdeki feminist hareketle ilgili olan son soruyu fazla genel bulduğu için yanttlamaktan kaçınmıştır.

\section{Sonuç}

Türkiye'de 200o'den bu yana feminist bir tiyatro topluluğu olarak varlığını sürdüren Tiyatro Boyalı Kuş ana akımın karşısında, feminist bir ideoloji benimsemiştir. Buradan hem sanat, hem politika yaptı̆̆ı çıarılabilir.

Ana akım tiyatroları ülkemizdeki ataerkil düzenin getirdiği hiyerarşik yapılanmadan kurtul(a)mazken, söz konusu feminist tiyatro kadın hareketinin başlıca koşulunu, "kolektif yapıyı ve bilinci" uygulamaktadır. Tiyatroda yer alan herkes oyun metninin seçiminden sahnelenmesine kadar işbirliği içinde çalışmaktadır. Katı bir yönetmen olgusu yoktur. Bazı çalışmalarda kadın seyirciler oyun yazarlarına, hatta oyunculara dönüşür. Feminist tiyatro karma yapıda olsa da, karar mekanizmasında kadınlar vardır.

Bahsi geçen feminist tiyatro cinsiyetçi dille yazılmış Türkçe oyunları "feminist dramaturji” tekniği ile yeniden okumanın yanı sıra, kadın oyunları yazmaktadır. Böylece kadını nesneleştiren, ona erkeklerin istediği cinsiyetçi roller veren geleneksel tiyatro metinleri yerine, kadınların kendilerini ilk ağızdan anlatabilecekleri ve hem sözleriyle, hem de bedenleriyle sahnede özne konumunda yer almalarını sağlayan feminist tiyatro metinleri üretilir ve oynanır.

$\mathrm{Bu}$ feminist tiyatronun ana akım tiyatrolar gibi düzenli ve sabit bir geliri yoktur. Yabancı oyun metinlerinin çevrilme sürecinde telif hakkı gibi hususlar ortaya çıktı̆̆ için, oyun metinlerini kendileri yazmayı tercih etmektedir. Tiyatro sınırlı bir bütçeyle ve gönüllülerle çalışmalarını sürdürmektedir.

Türkiye'deki feminist tiyatrolara dair genel bir bakış açısı sunmayı amaçlayan bu çalışmanın "Tiyatro Boyalı Kuş" ve bu tiyatronun kurucusu Jale Karabekir'in görüşme soruları çerçevesinde yaptığı değerlendirmeler ile sınırlı olduğunun altı çizilmelidir. Bu alanda daha detaylı bir araştırma için çeşitli oyun metinleri ve kayda alınan oyun performansları incelenebilir ve feminist tiyatrolar bünyesinde görev alan daha fazla kişi ile görüşmeler yapılabilir. Ülkemizde ana akım tiyatrolara alternatif olarak ortaya çıkan feminist tiyatroların ve onlarla ilgili yapılacak çalışmaların zamanla toplumun dönüşümüne katkıda bulunması kaçınılmazdır.

\section{Kaynakça}

3. Dalga $\quad$ Feminizm. (2017, $22 \quad$ Şubat). $\quad$ Erişim $\quad$ adresi https://leadercochise.wordpress.com/2017/02/22/3-dalga-feminizm/

Belkıs, Ö. (2015). Feminist Tiyatro. İstanbul: Mitos Boyut.

Case, S.-E. (2010). Feminizm ve Tiyatro. Ayşan Sönmez (Çev.). İstanbul: Boğaziçi Üniversitesi.

Georgia Highlands College. (2010, Mart 26). Virginia Woolf: "A Room of One's Own". Erişim adresi https://digital.films.com/p_ViewPlaylist.aspx?AssignmentId=ABPNDQ

Gül, S. (2009). Feminist Tiyatro Metninin Nitelikleri ve Model Oyunlarda Yansıması. (Yayımlanmamış Yüksek Lisans Tezi). Dokuz Eylül Üniversitesi/Güzel Sanatlar Enstitüsü, İzmir.

Haleva, B. (2014). Disiplinler Kavşağında Bir Durak: Çeviri. İstanbul: Ofis Yayınevi.

Hooks, B. (2016). Feminizm Herkes İçindir: Tutkulu Politika (4. Baskı). Ece Aydın, Berna Kurt, Şirin Özgün \& Aysel Yıldırım (Çev.). İstanbul: bgst Yayınları. 
Jale Karabekir. (t.y.) Erişim adresi https://tiyatrolar.com.tr/jale-karabekir

Karabekir, J. (2015). Türkiye'de Kadınlarla Ezilenlerin Tiyatrosu, Feminist Bir Metodolojiye Doğru. İstanbul: Agora Kitaplığı.

Kulak, A. \& Kırcalı, U. (2019). Kendine Ait Dört Oda; Virginia Woolf [4 Oda]. Erişim adresi https://www.nouvart.net/kendine-ait-dort-oda-virginia-woolf-dort-oda-umut-kircali-roportaji /. Mimesis, Tiyatro ve Çeviri Araştırma Dergisi. İstanbul: Boğaziçi Üniversitesi. Feminist Tiyatro Özel Sayısı. Sayı:12. Kasım 2006.

Öz, B. H. ve Belkıs, Ö. (2017). Türkiye'de Alternatif Tiyatro Yapılanmalarında Kadın Liderliği ve Bir Örnek: Yeşim Özsoy ve Galataperform. International Journal of Interdisciplinary and Intercultural Art. Cilt:2. Sayı:2. 1-22.

Pirpir, Y. (2018). Feminist Yayınevleri Ayizi ve Güldünya Örnekleri Işığında Türkiye’de Feminist Çeviri Yaklaşımlarına ve Feminist Çevirmen Kimliğine Genel Bakış. (Yayımlanmamış Yüksek Lisans Tezi). İstanbul Üniversitesi/Sosyal Bilimler Enstitüsü, İstanbul.

Savaşkan, T. (Ed.) (2018). DOSYA: Türkiye'de Feminist Tiyatro. TEB OYUN. İstanbul: Mitos Boyut. Sayı:39.

Şimşek, H. ve Yıldırım, A. (2016). Sosyal Bilimlerde Nitel Araştırma Yöntemleri (10. Baskı). Ankara: Seçkin.

Tayf Kolektif. (t.y.) Erişim adresi https://tiyatrolar.com.tr/tayfkolektif/?s=hakkinda

Tiyatro Boyalı Kuş. (2015, Ağustos). 2016-2017 Atölye Çalışmaları. Erişim adresi http://tiyatroboyalikus.blogspot.com/2015/o9/guz-2016-atolye-calismalari_28.html

Tiyatro Boyalı Kuş. (2015, Ağustos). Feminist Dramaturjiyle Okuma Tiyatrosu. Erişim adresi http://tiyatroboyalikus.blogspot.com/2015/o9/feminist-dramaturjiyle-okuma-tiyatrosu.html

Varlı, G. (2010). Üçüncü Tiyatro ve Türkiye'de Kadın Tiyatroları. (Yayımlanmamış Yüksek Lisans Tezi). Ankara Üniversitesi/Sosyal Bilimler Enstitüsü, Ankara.

Woolf, V. (1992). Kendine Ait Bir Oda. (S. Fırıncıoğlu, Der. ve Çev.). (Orijinal yayın tarihi, 1929). Erişim adresi https://isteyenokusun.files.wordpress.com/2014/11/kendine-ait-bir-oda_v-woolf.pdf

Yamaner, G. (2001). Yüzyıl Tiyatrosunda Kadın Bakış Açısının Yansımaları. Sanat-Tiyatro Eserleri Dizisi. Ankara: T.C. Kültür Bakanlığı.

Yamaner, G. (2002). Feminist Tiyatro Metinleri. Ankara: Dost Kitabevi. 


\section{EK: GÖRÜŞME SORULARI VE YANITLARI}

1.Tiyatro Boyalı Kuş ile Sayın Güzin Yamaner hocanın danışmanlığında yazılmış, “Üçüncü Tiyatro ve Türkiye'de Kadın Tiyatroları” adlı yüksek lisans tezi sayesinde (iyi ki) tanıştım. Ülkemizde özellikle 1990 sonrasında oluşum gösteren feminist tiyatro toplulukları arasında Tiyatro Boyalı Kuş da. Peki, feminist tiyatronun geleneksel tiyatrodan farkı nedir?

Geleneksel tiyatro denince kültürel olan bir performanstan bahsediliyor olabilir. Karagöz, Ortaoyunu, Köy Seyirlik vb. Biz alışlageldik, alışılan, bilinen anlamında kullanıyoruz. Eskiden geleneksel diye kullanmış olabiliriz, ama çeviri yanlışı oluyor, conventional demek istiyorsunuz diye düşünüyorum. Biz daha çok ana akım (mainstream) olarak kullanıyoruz artık. Sonuçta ana akıma karşı alternatif bir duruşumuz var ve bu duruşun ideolojisi de feminizm. Belki böyle söylemek daha doğru.

Feminist tiyatronun tanımını yapmak da çok zor. Literatürde bile eski ve Batı merkezli kategoriler var: Liberal, Marksist ve Radikal diye. Bakınca biz Tiyatro Boyalı Kuş olarak hiç birine girmiyoruz mesela ya da kendimizi bu kategorilerde tanımlamıyoruz. Ama bazen de bakıyoruz ki bu kategorilerdeki birçok özelliği barındırıyoruz. Yani bir açıdan da kendi ekibinizi kendiniz kuruyorsunuz, olmazsa olmazlar elbette var. Ancak biz çalışma yöntemlerimizden, ekip içindeki hiyerarşik düzene kadar, metin seçimi, metne bakış, sahneleme, oyunculuk, kostüm, ışık, müzik, ses her şeyi titizlikle düşünüyoruz, seyirciye seslendiğimiz her alanın (seyirciyi karşılama performansı da dahil) bizim iletimizde yeri var. Sonuçta kadın tiyatrosu değiliz, karma bir yapımız var. Karar mekanizmasında ise sadece kadınlar yer alıyor. Buna önem veriyoruz.

Ana akım tiyatrodaki yönetmen hiyerarşisi dahil olmak üzere, hiyerarşik düzene karşı durmaya çalışıyoruz. Ancak tiyatronun demokratik bir yapısı olmadığının da farkındayız. O nedenle elimizden geldiği kadar hiyerarşiyi azaltmaya yönelik yöntemlerimiz var. Biz yönetmen yerine reji demeyi tercih ediyoruz, reji de aslında hareket demek, ama yönetmek fiilinden türemiş bir kelimeden daha iyi geliyor kulağa.

Ana akımda ve tabii tiyatro tarihi boyunca yazılmış metinlerdeki eril bakış açısına da karşı durmaya çalışıyoruz. Yaptı̆̆ımız uyarlamalar, feminist dramaturji çalışmalarımız bunun göstergesi sayılabilir.

Oyunculuk anlamında da farklı yöntemleri denemeye çalışıyoruz, prodüksiyonumuza göre. Oyun dergisinde bunu farklı şekillerde anlatmaya çalıştım, çünkü üç ana dalda çalışıyoruz. Hepsinde de farklı denemelerimiz var. $\mathrm{Bu}$ dallardan/alanlardan öğrendiklerimizi, deneyimlerimizi bir diğerine aktarabiliyoruz. Bu da sanırım ana akımdan farklı.

Türkiye'deki alternatif tiyatro topluluklarından da farklılı̆ıımız var. Bazen alternatifin de alternatifi olduğumuzu düşünüyoruz.

Kadın imgesinin ve bedeninin nesne olarak temsili, cinsel obje olarak tekrar sahnede üretilmesi; cinsiyetçi sözler, cümleler, kalıplar; argonun sahneye taşınması gibi unsurlara da karşı durduğumuzu söyleyebiliriz.

2. Karşımızda eril öğelerle dolu bir dil ve toplum gerçeği var. Feminist tiyatro bu alışılagelmiş düzene/geleneklere nasıl "dur" diyor? Feminist tiyatro kuramının yapı bozuma uğrattı̆̆ı (ve yeni anlamlar yüklediği) kavramlar var mı? Bunlara örnekler verebilir misiniz?

Feminist dramaturji bizim çıkış noktamızdı. Belki de bizim sayemizde, tiyatro sahnesinde olduğumuz için, bu kavram da toplumda oturmaya başladı. Biz 200o'lerin başında feminist kelimesini özellikle kullanıyorduk, şimdiki gibi bir anlamı yoktu. 8 Mart Gece Yürüyüşü ve 25 Kasım Kadına Karşı Şiddet'e Dur Yürüyüşü bu kadar büyük bir kalabalıkla yapılmadığı bir dönemdi. Feminizm erkek düşmanlığı 
olarak vs. biliniyordu. Feminist olmamız ve feminist tiyatro yapmamız çok farklı algılanıyordu. Bu algının bugünden yarına dönüşmeyeceğinin farkındaydık ve sebat ettik. Dilin, kavramların değişmesi her şeyden daha önemli ama bir yandan da güç. Bu anlamda sahneleyeceğimiz metinlerin feminist dramaturjiyle ele alınması en önemli adımımız diyebiliriz.

Pek bir şeye dur diyebildiğimizi sanmıyorum. Ama feminist bir söylemin, pratiğin tiyatroda olabileceğinin 19 yıldır göstergesiyiz ve yeni nesil için de bir umut oluşturuyor. Ana akım, eril tiyatronun da artık göz ardı edemediği bir noktadayız. Sonuçta bizi yok sayamıyorlar. Ama bildikleri, alışlageldik tiyatroyu da yapmaya devam ediyorlar. Ancak artık meslektaşlarımız başta olmak üzere, seyircinin bu eril düşüncelerin, temsillerin, sahnelemelerin farkında olmaya başladığını da söyleyebiliriz. Bu önemli bir nokta. En azından bizim çalışmalarımızda farklı olabileceğini görüyor ve kıyaslama yapabiliyorlar.

Yapıbozum özellikle metin çözümlemelerinde feminist dramaturjiye önemli açılımlar açıyor. Ancak yeni kavramlardan bahsedersek, Oyun Dergisi'nde de detaylı bahsettiğim gibi Judith Butler'in performativite teorisi başta olmak üzere, Butler'ın parodi kavramı vs. bizim özellikle kullandığımız yöntemlerden. Özellikle bilinen metinlerde uygulamayı tercih ediyoruz.

3. Kadınlar yüzyıllardır hem sahnede, hem de gerçek hayatta kendilerine erkekler tarafindan biçilen rolleri oynamakta. Feminist tiyatro sahnesinde metin kurgusu ve beden kullanımı arasında nasıl bir ilişki seyreder? (oyuncu-beden-sahne-dil ilişkisi bağlamında kısaca bahsedebilir misiniz?)

Feminist tiyatro sadece metinden oluşmuyor, bunun sahnelemesi ve temsilleri de çok önemli. O nedenle bazı oyunlarımızın sadece metninden okuma yapmak imkânsız. Kendine ait Bir Oda ve Troyalı Kadınlar Korosu ve Kayıp Tablet benim sahne metnini oluşturduğum/yazdığım metinler. Açıçası sadece okunarak anlaşılması mümkün değil, çünkü sahneye konulmak üzere tasarlanmış. Çünkü sahneye uyarlarken bir yandan da o tonu, o hareketi hayal ediyorsunuz. Bu çok önemli. Feminist tiyatro ayrıca adından yani tiyatrodan anlaşılacağı gibi bir performans, gösteri. Bu anlamda beden, dil de ana akım tiyatrodan farklı ele alınıyor. Tabii diksiyon, artikülasyon gibi dikkat ettiğimiz noktalar var, ancak örneğin vurguyu klasik tarzla yapmıyoruz. Klasiği kırdığımız bir nokta var, eğer bizim amacımıza uygunsa. Dili yabancılaştırmıyoruz, ama dilin içindeki bazı kuralları değiştiriyoruz. Bunu seyircinin anlamı için fazla dikkatli olması gerekiyor tabii. Dilin eril yapısını değiştirmek, cinsiyetçi yapıları kullanmamak, kadını nesne değil, özne yapmak, sözü ve aksiyonu kadından yana kullanmak önem verdiğimiz noktalar. Bu anlamda konservatuvar mezunları ile çalıştığımız zaman, çoğunlukla öğrendikleri ana akım kalıpları yıkmakla uğraşıyoruz. Bu da çok kolay bir şey değil. Kişinin, oyuncunun bu değişimi istemesi gerekiyor. En önemli noktamız oyuncunun sahteliği. Ülkemizde de dünyada da sahte bir oyunculuk eğitimi alınıyor. Oyuncunun sahnedeki sahte hareket ve sözlerini, gerçek ve samimi haline dönüştürmek en önemli amacımız. Her zaman bu konuda başarılı olamıyoruz ama bunun da önemli bir adım olduğunu biliyoruz. Sahnede samimi olmak hem metin hem oyuncu açısından çok önemli, çünkü tiyatro iki taraflı bir performans, seyirci ile oyuncu arasında gidip gelen. Bu ilişkinin de gerçekten samimi olması lazım.

4.Tiyatro Boyalı Kuş'un internet sitesinde bir tarama yaptığımda bugüne kadar oynanan oyunların tamamına yakınının Türkçe olduğunu gördüm. Bunun özel bir sebebi var mıdır? (kültürel, sosyal, politik vb.) Gelecekte yabancı oyunlara da yer vermeyi düşünüyor musunuz?

19 yll içinde birbirinden farklı prodüksiyonlarımız oldu. August Strindberg, Henrik Ibsen, Caryl Churchill, Svetlana Aleksiyeviç gibi yabancı yazarların oyunlarını sahneledik. Shakespeare, Aristofanes ve Evripidis gibi yazarların metinlerinden yola çıkarak yeni metinler ürettiğimizi de söyleyebilirim. $\mathrm{O}$ sezonda yapmak istediğimiz, dert edindiğimiz meseleler üzerine oyun yapıyoruz.

Ibsen’in Nora-Bir Bebek Evi oyununu örneğin Türkçe değil, Kürtçe olarak sahneledik. Ancak Türkçe çevirisi (Jale Karabekir-Feride Eralp) Agora Kitaplı̆̆ı'ndan 2012 yılında basıldı ve 2018 yılından beri 
İstanbul Şehir Tiyatrosu'nda bu çeviriyle oynuyor. Bu da çeviri anlamında bir katkımız sayılabilir ana akım tiyatroya.

Feminist oyun metni bulmanın zorlukları, yeni yazılmış feminist metinlerin de bize, seyirciye ve/veya bu topluma uygunluğu gibi meseleler nedeniyle tercih etmemiş olabiliriz. (Her kadın oyunu feminist bir metin olmuyor ya da bizim ekiple benzer feminist görüşte olmayabiliyor ya da çok Batılı söylemler/görüşler içerebiliyor vs. gibi sebepler de olabiliyor.) Ancak ekibimiz dramaturji kökenli olduğu için de, yeni yazılmış metinlere -özellikle de ekibimizdeki kişilerin ya da ekibimize yakın olan kişilerin yazdıkları- sahnemizi açmayı da önemli buluyoruz.

Bir başka sebep de, 2014 ylından beri sabit bir bütçeye/fona sahip olmamamızdan ileri gelen, ülkenin ekonomik ve politik baskıları dolayısıyla da telif (yazar ve çevirmen) oyunları oynamanın mali yükünü kaldıramayacağımızın bilincindeyiz.

Feminist Dramaturjiyle Okuma Tiyatrosu bağlamında ise evet haklısınız. Tamamen eski Türkçe metinler üzerine çalışıyoruz. İşte tam da orada, bu eski metinlere yeni bir okuma yapmaya çalışıyoruz.

5. Okumalarım sonucu feminist tiyatro topluluklarının güncel konuları işlemek adına oyun metinlerini çoğunlukla kendilerinin yazdığı ya da eril bir dille kaleme alınmış metinleri uyarladı̆̆ı sonucuna vardım. Bu metinler sadece kadınlara mı seslenmekte? Feminist tiyatronun kadın sorunlarının çözümüne katkısı nedir?

Son oyunumuz "Kendine Ait Bir Oda"nın kadınlara seslendiğini düşünüyorum. Çünkü özellikle kadın seyirciler çok etkileniyor, erkek seyirciler için sanırım farklı bir deneyim oluyor. Ancak bu metnin getirdiği bir kısıtlama ya da sınırlama olduğunu düşünüyorum. diğer oyunlarımızda sadece kadınlara seslenen bir tercihimiz olmadı. Dönüşümün tüm toplumda olması gerektiğinin farkındayız. Topluluğumuzun karma olmasının nedenlerinden biri de bu. Feminist tiyatro kadın sorunlarını çözebilir mi, bilmiyorum. Tiyatronun bu tür bir gücü olduğunu sanmıyorum bu yaşadığımız dönemde. Sosyal medya ve sanallık daha etkili. Bu etki de sanal olabilir tabii. Tiyatro gerçek ilişkiyi temsil ediyor benim için, insani olan. Etkileşimin gerçek olduğu, o nedenle samimi olması şart. Ezilenlerin Tiyatrosu bu anlamda daha katılımcı ve daha etkileşimli bir yöntem. Kadın meselelerine yaklaşım ve bilinç yükseltme açısından daha etkili buluyorum. Zaten bizim de çalıştığımız bir dal bu.

6. Virginia Woolfün "Kendine Ait Bir Oda" adlı eserini 12 Mayıs Pazar günü Cihangir Performans'ta Tiyatro Boyalı Kuş yorumu ile izledim. Sizinle de oyun sonrası kısa bir sohbet şansını yakaladım. Bu eserin çevirisi ve sahne metnine dönüştürülmesi sizin elinizden çıktı. Bu süreçten biraz bahsedebilir misiniz? (bu eseri neden seçtiğiniz, çeviri yaparken dikkat ettiğiniz dilsel-kültürel noktalar, kaynak metne ne kadar bağlı kaldığınız vb.)

$\mathrm{Bu}$ yıl planlama yapmadığımız halde, ekibimizden bazı üyelerin de göç etmesi sebebiyle yeni bir ekip oluşturduk. Bu ekiple metin olmadan, ne yapacağımız bilmeden çalışmalara başladık. Cihangir Performans'ta bu çalışmalar gerçekleşti. 20 Kasım 2018 bizim başladığımız tarihti. Biz ekibe ilk gelen kişilere iki kitap öneriyoruz: Biri "Kendine Ait Bir Oda", diğeri "Feminist Teori". Yıllardır bunu yapıyoruz. Bu yıl yeni dramaturg arkadaşımız Yeliz "Kendine Ait Bir Oda"dan çok etkilendiğini söyleyerek çalışmaya geldi. Siz de gördünüz, mekanımız odalardan oluşuyor. Benim de ara ara okuduğum bir metindir "Kendine Ait Bir Oda”. Onun heyecanı bana da bulaştı ilk an. Ve sahnelenebilir mi acaba diye o gözle okumaya başladım. Göç etmiş olan eski dramaturg arkadaşımızın yanına gitmiştik, onunla da konuştuk. Derken, dramaturji toplantıları yapmaya başladık, bir yandan da fiziksel olarak çalışmaya yani metin olmadan prova yapmaya devam ediyorduk. "Kendine Ait Bir Oda"nın içerdiği aksiyon, hareket ve temalar üzerine doğaçlamalar yapıyorduk. Derken bölüm bölüm metnin dramaturjisini yapmaya ve Türkçeleştirmeye ve sahneye uyarlamaya başladım. Metin hiyerarşisi olmadan bu yeni ekiple çalıştığımız için, aslında hem yeni bir ekip ruhu oluştu, hem de oyuncunun bedensel hareket ve yaratım özgürlüğünü yakalama firsatı bulduk. Daha sonra oyuncularla da metindeki 
temalar ve bizim ekip olarak o temalara yakınlığımız, uzaklığımız, kendi engellerimiz vs üzerine tartıştık ve çalıştık. Ve 7 Nisan 2019'da ilk defa seyirciyle buluştuk. Bu kadar kısa bir zamanda böyle bir performansı çıkarmak çok güç, hem de yepyeni bir ekiple ancak, hem mekanın bize tanıdığı firsatlar hem metnin güçlülüğü ve hala evrensel ve güncel olması, tabii bunda Virginia Woolf un kaleminin çok büyük payı var, bizim bu oyunu severek çıkarmamızı sağladı. En önemli çıkarımımız da sanırım, "Kendine Ait Bir Oda”nın bizim için aslında fiziksel bir oda değil, Tiyatro Boyalı Kuş’un kendisi olduğunu fark etmemiz oldu. Bu oyuna daha da farklı sarılmamızı sağlıyor.

\section{Oyunun beş kadın oyuncu tarafindan oynanmasının bir anlamı var mıdır? Oyuncular neden siyah kıyafetler içindelerdi?}

Beş oyuncuyla oynanmasının subliminal bir anlamı olabilir. Ancak bizim bilinçli bir şekilde bunu kurgulamadığımızı söyleyebilirim. (Geçen seneki Troyalı Kadınlar Korosu ya da Kayıp Tablet oyunumuz da, beş kişilik bir kadın korosundan oluşuyordu). Üç, beş, yedi ve dokuz kadim rakamlar. Ancak baktığımızda günümüz koşullarında provaların ve gösterimlerin sağlıklı yürütülebilmesi için de oyuncu sayısının, ekibin özelliğine göre, makul olması da gerekiyor.

Siyah sahnede nötr bir renk. Virginia Woolf, kadın üniversitesinde kadın öğrencilere bir konuşma yapıyor. Woolf un bilinçakışı yöntemini kullandığını biliyoruz, bu metinde de kullanıyor, bunu sahnelemede nasıl gösterebiliriz diye düşününce, bu bilinçakışını farklı düşüncelerin oyun yerinde bedenleşmesi ve Woolf'la ve seyirciyle konuşması olarak bulduk. Diğger dört oyuncu Woolf un zihnindeki düşünceleri temsil ediyor. Çoğunlukla cinsiyetsizler. Şekilden şekile girebiliyorlar, kişiden kişiye dönüşebiliyorlar, çünkü kişi değil düşünceler. O nedenle bu fikrimizi seyirciye verebilmek için de nötr bir renk ve kostümde karar kıldık.

8.Bu oyunda beni çok etkileyen sözlerden biri; "Kütüphanedeki kitapları mı kadınlardan koruyorlar, kadınları mı kitaplardan?” Bugün ülkemizde feminist hareketin geldiği noktayı ve bu hareketin kadınlara yansımasını nasıl görüyorsunuz?

Soru genel bulunduğu için yanıtlanmadı. 